\title{
28 Research Soure \\ The Effects of Onlay Titanium-coated Mesh on Recurrence, Foreign Body Feeling and Chronic Pain in Ventral Hernia
}

Çağrı Akalın ( $\sim$ dr.cagriakalin@gmail.com )

Research article

Keywords: Ventral hernia, titanium-coated mesh, polypropylene mesh, recurrence, foreign body feeling, chronic pain

Posted Date: May 15th, 2020

DOI: https://doi.org/10.21203/rs.3.rs-28335/v1

License: @ (1) This work is licensed under a Creative Commons Attribution 4.0 International License. Read Full License 


\section{Abstract}

Background There are many complications of meshes in hernia repair. The aim of this study was to investigate the effects of onlay titanium-coated meshes (TCM) on recurrence, foreign body feeling and chronic pain in ventral hernia repair.

Methods In this retrospective cohort study, patients who underwent TCM and polypropylene mesh (PM) for onlay repair of ventral hernia were examined between May 2014 and January 2018 at our centre. Patient characteristics, type of hernia, defect size, operative time, follow-up time, surgical site occurrence (infection, seroma and hematoma), recurrence, foreign body feeling and chronic pain were analysed. Patients were divided into two groups according to the mesh elected; TCM (titanium group) or PM (polypropylene group).

Results Out of 160 patients, 63 (32.6\%) had TCM and 97 (67.4\%) had PM. There was no significant difference between groups in terms of recurrence $(p=0.757)$. Chronic pain and foreign body feeling were low in the titanium group ( $p=0.047$ and $p=0.029$, respectively), a positive correlation was found between surgical site infection and recurrence $(p=0.020)$. In the polypropylene group, an increase in defect size was significantly associated with foreign body feeling and chronic pain ( $p<0.001$ for both comparisons).

Conclusion In onlay repair of ventral hernia, TCM led to less foreign body feeling and chronic pain then PM. The surgical site infection was associated with recurrence for these meshes. Additionally, the increase in defect size causes a risk for foreign body feeling and chronic pain in repair using PM.

\section{Backgrounds}

A ventral hernia $(\mathrm{VH})$ is the protrusion of organs or tissue, spontaneously (primary) or in the area of a surgical incision (incisional hernia), in the abdominal wall. VH, in addition to causing complaints like pain and swelling, carries potential risk in terms of incarceration [1]. There are open and laparoscopic approaches for ventral hernia repair (VHR) with meshes at present. Furthermore, in open VHR, there are many techniques (onlay, sublay, inlay and preperitoneal) depending upon the placement of the mesh. There is no consensus on the ideal location for mesh placement in open VHR. The onlay open VHR is typically performed with placement of the mesh above the anterior muscle sheath [2].

To date, VHR can still cause high morbidity and recurrence [3]. The rate of recurrence can increase to $63 \%$ after closing with primary sutures. Recurrence rates generally decrease significantly after using a synthetic mesh in hernia surgery [4]. Even though synthetic meshes have some advantages such as high tensile strength and costefficiency, they also have negative effects such as seroma, fistula formation and chronic pain [5]. Therefore, in order to decrease complications with the help of advanced technology, many meshes were produced and these meshes were classified according to their weight and pore intervals [6]. One of these meshes, composite titanium-coated meshes (TCM), was obtained by coating polypropylene with titanium dioxide, and it has multiple weight and pore intervals. TCM has begun to be used for ventral and inguinal hernia repair in both open and laparoscopic surgery within the last two decades. A review by Köckerling et al. stated TCM requires less analgesia in the postoperative period and ensured earlier return to work when used for laparoscopic incisional hernia repair and recommended it at statement level 1B [7]. However, the authors made no statement or recommendations about the use of TCM in open VHR. In the literature, there is no clear information about the effects of TCM on recurrence, foreign body feeling and chronic pain in onlay VHR. 
The aim of this study is to evaluate the effects of TCM on recurrence, foreign body feeling and chronic pain in onlay VHR.

\section{Methods}

\section{Study design}

A single-centre cohort study was designed retrospectively and ethics committee approval for the study was obtained from XXX. At XXX, patients who had elective repair for VH underwent between May 2014 and January 2018 were analysed. In patients, polypropylene mesh (PM) (Proline, Ethicon, Holland) with heavyweight $\left(80 \mathrm{~g} / \mathrm{m}^{2}\right)$ and low pore size (0.8-1.2 mm) and titanium dioxide-coated $\mathrm{PM}\left(\mathrm{TiO}_{2}\right.$, BioCer, Bayreuth, Germany) with lightweight $\left(47 \mathrm{~g} / \mathrm{m}^{2}\right)$ and wide pore size $(2.8 \mathrm{~mm}$ ) were used. Mesh selection was randomized and was not made according to any patient characteristics. Patients were divided into two groups according to the mesh elected; TCM (titanium group) or PM (polypropylene group). Informed consent about surgery was obtained from patients before an operation.

\section{Patients selection}

Patients who elective underwent onlay VHR were approached in the study. The inclusion criteria included: (1) over 18 years of age, (2) using TCM or PM, (3) defect size measured with ultrasound examination prior to operation. The exclusion criteria included: (1) under 18 years of age, (2) strangulated hernia, (3) a medical history of ostomy or malignancy, (4) ASA scores $\geq 4$, (5) a history of chemotherapy or radiotherapy, (6) patients whose information could not be accessed, (7) exitus in the follow-up period.

\section{Surgical technique}

All operations were performed with general anaesthesia in supine position by the same surgeon. A single dose of antibiotic (Cefazolin sodium, $1 \mathrm{~g}$, Eczacıbaşı Drug Industries, Istanbul) was administered intravenously within 30 minutes of the surgical incision. An incision on the hernia localization passed the skin and then under the skin, and the fascial defect was revealed. The hernia sac was carefully opened and separated from the adjacent tissues by a combination of blunt and sharp dissection. After that, the hernia sac was closed with continuous sutures using $3 / 0$ vicryl (polyglactin 910, Ethicon, USA). Then the posterior sheath was closed with 2/0 vicryl (polyglactin 910, Ethicon, USA) and the anterior sheath was closed with an absorbable no. 1 polydioxanone suture (PDS, Ethicon, Holland). TCM and PM were fixed with 2/0 polypropylene suture to the anterior sheath. The meshes were positioned according to the defect size in order to safely close the surgical site (in such a way that it would encompass $5 \mathrm{~cm}$ around). Patients with defect size larger than $3 \mathrm{~cm}$ and/or with large dissection had a hemovac drain inserted in the surgical site. Subcutaneous tissue was closed with 3/0 vicryl suture (polyglactin 910, Ethicon, Holland) and skin was sutured with 3/0 polypropylene suture (Proline, Ethicon, Holland). Operative time was regarded as the time between the administration of infiltration anaesthesia and skin closure.

\section{Collected information}

The following data were collected using the electronic medical records: age, gender, body mass index (BMI), comorbidities, American Society of Anesthesiologists (ASA) score, smoking habits, type of hernia, defect size (cm), 
operative time (min), follow-up time (months), surgical site occurrence, foreign body feeling and chronic pain. Comorbidities included cardiovascular diseases (hypertension, congestive heart failure, coroner artery disease, cardiac arrhythmia, peripheral vascular disorders), respiratory diseases (asthma, chronic obstructive pulmonary disease, chronic bronchitis and emphysema), diabetes mellitus and chronic renal failure. Hernia type was classified according to the European Hernia Society (EHS). Hernia defect size was defined as longest diameter (length or width) of the sheath defect by specialist radiologist with ultrasound examination before the operation. Follow-up was performed by the same surgeon. Surgical site occurrences were defined as surgical site infection (SSI), seroma and hematoma.

Clinical evaluation was routinely done for all patients at periods of 1 week, 2 weeks, 1 month, 3 months, 6 months and 12 months. Patients not attending clinical check-ups were called up by telephone and called to the outpatient clinic (1-year follow up). All patients were then followed in the outpatient clinic during the follow-up period if presented signs or symptoms (pain, swelling etc.).

Recurrence was defined as occurrence of the hernia in the previous surgery site. Patients with symptoms (pain, swelling etc.) had clinical examination for recurrence performed in the supine position. A validation with ultrasound examination (by the specialist radiologist) was been conducted when suspicious results were found on physical examination. Recurrence was determined by clinical and ultrasound examination. Additionally, the patients were asked questions about foreign body feeling and pain. Patients were asked: "Is there any foreign body feeling in the operative region?" for foreign body feeling. Results were recorded as "yes" or "no". The pain status of patients was assessed with the visual analogue scale (VAS). The pain condition of patients was rated from 0 (no pain) to 10 (worst pain imaginable) according to the visual analogue scale (VAS). Chronic pain was defined as pain in the operative region for more than 6 months after surgery in the last 30 days assessed using the VAS ( $\geq 3$ : chronic pain) [8]. The questions on the pain questionnaire included pain while at rest, coughing and during physical activity.

\section{Statistical analysis}

In this study, descriptive statistics for continuous variables are given as mean, standard deviation, minimum and maximum values and expressed as number and percentage for categorical variables. The data distribution was evaluated using the Kolmogorov-Smirnov test. The chi-square test and Fisher's exact test were used to identify the relationship between categorical variables. The Mann-Whitney $U$ test was performed in relation to continuous variables. In calculations, the SPSS statistical software package (IBM SPSS for Mac, Version 24.0) statistics package software was used for calculations and $p$ values less than 0.05 were considered statistically significant.

\section{Results}

In this study, enrollment of 192 patients was completed between May 2014 and January 2018. A total of 32 patients were excluded as they were lost to follow-up and 160 patients who met the inclusion criteria enrolled (Fig. 1). The groups were similar with regard to age, gender, BMI, comorbidities, ASA score, smoking habits and surgical site reoccurrence. In all groups, 7 of 23 patients with SSI had seroma (30.4\%), while 9 of 129 patients with non-SSI had seroma (6.9\%). In the titanium group, seroma was detected in all patients with SSI $(n=5)$, a positive correlation was found between seroma and SSI $(p<0,001)$. In the polypropylene group, seroma was detected in 2 of the patients with SSI (15,4\%). No significant correlation was found between seroma and SSI in the polypropylene group ( $p=$ 0.291). Patient and surgical site reoccurrence characteristics are presented in Table 1. 
Table 1

Patient and surgical site reoccurrence characteristics

\begin{tabular}{|c|c|c|c|}
\hline & Titanium group $(n=63)$ & Polypropylene group $(n=97)$ & $p$ value \\
\hline Age (years) & $58.57 \pm 11.93(28-74)$ & $55.81 \pm 12.77(26-75)$ & 0.852 \\
\hline $\begin{array}{l}\text { Gender } \\
\text { Female (\%) } \\
\text { Male (\%) }\end{array}$ & $\begin{array}{l}36(57.1) \\
27(42.9)\end{array}$ & $\begin{array}{l}54(55.7) \\
43(44.3)\end{array}$ & 0.861 \\
\hline BMI $\left(\mathrm{kg} / \mathrm{m}^{2}\right)$ & $29.79 \pm 3.47(18.3-36.9)$ & $29.61 \pm 3.26(19.4-36.5)$ & 0.835 \\
\hline $\begin{array}{l}\text { Comorbidities } \\
\text { Cardiovascular (\%) } \\
\text { Respiratory (\%) } \\
\text { DM (\%) } \\
\text { CRF }(\%)\end{array}$ & $\begin{array}{l}15(23.8) \\
5(7.9) \\
8(12.7) \\
2(3.2)\end{array}$ & $\begin{array}{l}24(24.7) \\
6(6.2) \\
5(5.2) \\
3(3.1)\end{array}$ & 0.523 \\
\hline $\begin{array}{l}\text { ASA score } \\
1(\%) \\
2(\%) \\
3(\%)\end{array}$ & $\begin{array}{l}23(36.5) \\
31(49.2) \\
9(14.3)\end{array}$ & $\begin{array}{l}23(23.7) \\
55(56.7) \\
19(19.6)\end{array}$ & 0.162 \\
\hline Smoking & $10(15.8)$ & $21(21.6)$ & 0.421 \\
\hline \multicolumn{4}{|c|}{ Surgical site reoccurrence } \\
\hline SSI & $10(15.9)$ & $13(13.4)$ & 0.663 \\
\hline Seroma & $8(12.7)$ & $8(8.2)$ & 0.359 \\
\hline Hematoma & $3(4.8)$ & $3(3.1)$ & 0.681 \\
\hline
\end{tabular}

The VAS scores were not different between the two groups $(p>0.05)$. The overall VAS scores during physical activity are shown in Table 2.

Table 2

VAS scores in patientsa

\begin{tabular}{|c|c|c|c|}
\hline & Titanium group $(n=63)$ & Polypropylene group $(n=97)$ & $\mathrm{p}$ value \\
\hline $\begin{array}{l}\text { VAS } \\
0 \\
1 \\
2 \\
3 \\
4 \\
\geq 5\end{array}$ & $\begin{array}{l}53(84.1) \\
4(6.3) \\
6(9.5) \\
- \\
- \\
-\end{array}$ & $\begin{array}{l}84(86.6) \\
5(5.2) \\
2(2.1) \\
4(4.1) \\
2(2.1) \\
-\end{array}$ & 0.082 \\
\hline \multicolumn{4}{|c|}{$\begin{array}{l}\text { Percentages are in parenthesis } \\
\text { VAS visual analogue scale; pain severity was estimated by the VAS scale from } 1 \text { to } 10 \\
\text { a Pain during physical activity }\end{array}$} \\
\hline
\end{tabular}

The mean operative time was $63.76 \pm 17.75 \mathrm{~min}$ in the titanium group and $60.95 \pm 12.76 \mathrm{~min}$ in the polypropylene group. The mean follow-up time was $28.52 \pm 11.15$ months in the titanium group and $28.21 \pm 12.76$ months in the 
polypropylene group (range 12-47 months for both groups). No significant difference was found between two groups regarding both the operative time $(p=0.716)$ and the follow-up time $(p=0.894)$.

Recurrence was detected only in one patient in each group, and no significant correlation was found between groups in terms of recurrence $(p>0.05)$. In the titanium group, foreign body feeling and chronic pain (during physical activity) were statistically lower than in the polypropylene group $(p<0.05)$. Recurrence, foreign body feeling and chronic pain information of all patients are presented in Table 3.

Table 3

Recurrence, foreign body feeling and chronic pain information in patients

\begin{tabular}{|llll|}
\hline & $\begin{array}{l}\text { Titanium group } \\
(\mathbf{n = 6 3 )}\end{array}$ & Polypropylene group $(\mathbf{n = 9 7 )})$ & $\mathbf{p}$ value \\
\hline Recurrence & $1(1.6)$ & $1(1)$ & 0.757 \\
\hline Foreign body feeling & $1(1.6)$ & $11(11.3)$ & 0.029 \\
\hline $\begin{array}{l}\text { Chronic pain } \\
\text { Pain at rest } \\
\text { Pain during coughing }\end{array}$ & - & $1(1)$ & 0.606 \\
Pain during physical activity & - & $3(3.1)$ & 0.220 \\
\hline \multicolumn{2}{l}{ Percentages are in parenthesis } & $6(6.2)$ & \\
\hline
\end{tabular}

Time to recurrence was 9 months in the titanium group and 14 months in the polypropylene group. Recurrence was identified on the sheath suture line (centre of the mesh) in two patients. The defect size in recurrence was $11 \mathrm{~mm}$ in the titanium group and $20 \mathrm{~mm}$ in the polypropylene group. Additionally, of 13 patients with DM, 10 were using oral antidiabetic drugs, while 3 were receiving insulin treatment (two patients in the titanium group, one patient in the polypropylene group). In 12 of these patients, haemoglobin $\mathrm{A} 1 \mathrm{c}(\mathrm{HbA} 1 \mathrm{c})$ levels were $<7 \%$, with 1 (in the polypropylene group) $>7 \%$. Recurrence was identified in the patient with $\mathrm{HbA} 1 \mathrm{c}$ level $>7 \%$. In all group, no significant differences were found between comorbidities with recurrence $(p=0.076)$. SSI was observed patients with DM $(n=$ 2 ) and the positive correlation was found between SSI and recurrence $(p=0.020)$. Foreign body feeling was identified in 12 patients, with 4 having chronic pain and all 4 of these patients were in the polypropylene group. The defect size was associated with increased foreign body feeling and chronic pain ( $p<0.05$, for all comparisons). The patient information related to these complications are shown in Table 4. 
Table 4

Characteristics of recurrence, foreign body feeling and chronic pain

\begin{tabular}{|c|c|c|c|c|c|c|c|c|c|}
\hline & \multicolumn{3}{|c|}{ Recurrence } & \multicolumn{3}{|c|}{ Foreign body feeling } & \multicolumn{3}{|c|}{ Chronic pain ${ }^{a}$} \\
\hline & $\begin{array}{l}\text { TG } \\
(\mathrm{n}= \\
1)\end{array}$ & $\begin{array}{l}P G \\
(n= \\
1)\end{array}$ & $\begin{array}{l}p \\
\text { value }\end{array}$ & $\begin{array}{l}\text { TG } \\
(n= \\
1)\end{array}$ & $\begin{array}{l}P G \\
(n=11)\end{array}$ & $\begin{array}{l}p \\
\text { value }\end{array}$ & $\begin{array}{l}T G \\
(n= \\
0)\end{array}$ & $\begin{array}{l}P G \\
(n=6)\end{array}$ & $\begin{array}{l}\mathrm{p} \\
\text { value }\end{array}$ \\
\hline Age (years) & 51 & 74 & 0.130 & 49 & $\begin{array}{l}61.9 \pm \\
7.7\end{array}$ & 0.170 & - & $\begin{array}{l}59.1 \pm \\
8.5\end{array}$ & 0.571 \\
\hline $\begin{array}{l}\text { Gender } \\
\text { Female } \\
\text { Male }\end{array}$ & $\begin{array}{l}1 \\
-\end{array}$ & $\begin{array}{l}1 \\
-\end{array}$ & 0.505 & $\begin{array}{l}1 \\
-\end{array}$ & $\begin{array}{l}7 \\
4\end{array}$ & 0.449 & - & $\begin{array}{l}4 \\
2\end{array}$ & 0.697 \\
\hline $\mathrm{BMI}\left(\mathrm{kg} / \mathrm{m}^{2}\right)$ & 28.9 & 31.4 & 0.271 & 24.3 & $\begin{array}{l}29.8 \pm \\
2.9\end{array}$ & 0.845 & - & $\begin{array}{l}31.5 \pm \\
2.4\end{array}$ & 0.158 \\
\hline $\begin{array}{l}\text { Comorbidities }{ }^{\mathrm{b}} \\
\text { Cardiovascular } \\
\text { Respiratory } \\
\text { DM } \\
\text { CRF }\end{array}$ & $\begin{array}{l}- \\
- \\
1 \\
-\end{array}$ & $\begin{array}{l}1 \\
- \\
1 \\
-\end{array}$ & 0.076 & $\begin{array}{l}- \\
- \\
- \\
-\end{array}$ & $\begin{array}{l}5 \\
2 \\
1 \\
-\end{array}$ & 0.441 & $\begin{array}{l}- \\
- \\
- \\
-\end{array}$ & $\begin{array}{l}3 \\
1 \\
1 \\
-\end{array}$ & 0.629 \\
\hline $\begin{array}{l}\text { ASA score } \\
1 \\
2 \\
3\end{array}$ & $\begin{array}{l}- \\
1 \\
-\end{array}$ & $\begin{array}{l}- \\
- \\
1\end{array}$ & 0.376 & $\begin{array}{l}1 \\
- \\
-\end{array}$ & $\begin{array}{l}1 \\
8 \\
2\end{array}$ & 0.170 & $\begin{array}{l}- \\
- \\
-\end{array}$ & $\begin{array}{l}1 \\
4 \\
1\end{array}$ & 0.184 \\
\hline Smoking & - & - & 0.352 & 1 & 4 & 0.250 & - & 2 & 0.410 \\
\hline \multicolumn{10}{|l|}{$\begin{array}{l}\text { Surgical site } \\
\text { reoccurrence }\end{array}$} \\
\hline SSI & 1 & 1 & 0.020 & - & 1 & 0.461 & - & - & 0.595 \\
\hline Seroma & - & - & 0.515 & - & 1 & 0.838 & - & 1 & 0.457 \\
\hline Hematoma & - & - & 0.695 & - & 1 & 0.378 & - & - & 0.622 \\
\hline \multicolumn{10}{|c|}{$\begin{array}{l}\text { TG titanium group, PG polypropylene group, BMI body mass index, DM diabetes mellitus, CRF chronic renal } \\
\text { failure, SSI surgical site infection } \\
\text { a Pain during physical activity } \\
\text { b Some patients had more than one comorbid disease }\end{array}$} \\
\hline
\end{tabular}

In the titanium group, recurrence is determined after umbilical hernia repair $(n=1)$ while foreign body feeling observed after epigastric hernia repair $(n=1)$. When the defect width (W) (for incisional hernia in EHS classification) of all patients in the study are assessed; $29(36.5 \%)$ had W1 $(<4 \mathrm{~cm})$ class hernias and $31(38.6 \%)$ had W2 $(4-10 \mathrm{~cm})$ class hernias identified. In both groups, foreign body feeling was significantly higher among patients with incisional hernia repair and W2 class hernia ( $p=0.029, p=0.027$, respectively). Foreign body feeling was not observed after incisional hernia repair in the titanium group. The polypropylene group was examined separately; foreign body feeling was significantly higher patients with incisional hernia repair and W2 class hernia $(p=0.020, p=0.005$, respectively). The defect sizes of patients with foreign body feeling and chronic pain were significantly higher in the polypropylene group than in the titanium group $(p<0.05)$. The increase in defect size was related to foreign body feeling and chronic pain in polypropylene group ( $p<0.001$, for both comparisons). Hernia classification of the groups according to EHS and complications are shown in Table 5. 
Table 5

Hernia classification and complications of all patients

\begin{tabular}{|c|c|c|c|c|c|c|c|c|c|c|c|c|}
\hline & \multicolumn{3}{|c|}{ Recurrence $(n=2)$} & \multicolumn{3}{|c|}{$\begin{array}{l}\text { Foreign Body } \\
\text { Feeling }(n=12)\end{array}$} & \multicolumn{3}{|c|}{ Chronic Pain $(n=6)$} & \multicolumn{3}{|c|}{ All patients $(n=160)$} \\
\hline & $\begin{array}{l}\text { TG } \\
(\mathrm{n} \\
= \\
1)\end{array}$ & $\begin{array}{l}P G \\
(n \\
= \\
1)\end{array}$ & $\begin{array}{l}\mathrm{p} \\
\text { value }\end{array}$ & $\begin{array}{l}\text { TG } \\
(\mathrm{n} \\
= \\
1)\end{array}$ & $\begin{array}{l}P G \\
(n \\
= \\
11)\end{array}$ & $\begin{array}{l}\mathrm{p} \\
\text { value }\end{array}$ & $\begin{array}{l}\text { TG } \\
(\mathrm{n} \\
= \\
0)\end{array}$ & $\begin{array}{l}P G \\
(n \\
= \\
6)\end{array}$ & $\begin{array}{l}\mathrm{p} \\
\text { value }\end{array}$ & $\begin{array}{l}T G \\
(n= \\
63)\end{array}$ & $\begin{array}{l}P G \\
(n= \\
97)\end{array}$ & $\begin{array}{l}\mathrm{p} \\
\text { value }\end{array}$ \\
\hline $\begin{array}{l}\text { Hernia type } \\
\text { Umbilical } \\
\text { Epigastric } \\
\text { Incisional }\end{array}$ & $\begin{array}{l}1 \\
- \\
-\end{array}$ & $\begin{array}{l}- \\
- \\
1\end{array}$ & 0.80 & $\begin{array}{l}- \\
1 \\
-\end{array}$ & $\begin{array}{l}1 \\
1 \\
9\end{array}$ & 0.029 & $\begin{array}{l}- \\
- \\
-\end{array}$ & $\begin{array}{l}1 \\
- \\
5\end{array}$ & 0.082 & $\begin{array}{l}25 \\
(39.7) \\
14 \\
(22.2) \\
24 \\
(38.1)\end{array}$ & $\begin{array}{l}42 \\
(43.3) \\
19 \\
(19.6) \\
36 \\
(37.1)\end{array}$ & 0.259 \\
\hline $\begin{array}{l}\text { Defect size } \\
(\mathrm{cm})\end{array}$ & 3.6 & 6 & 0.401 & 3 & $\begin{array}{l}6.6 \\
\pm \\
2.5\end{array}$ & $\begin{array}{l}< \\
0.001\end{array}$ & - & $\begin{array}{l}7.8 \\
\pm \\
2.9\end{array}$ & 0.001 & $\begin{array}{l}4.8 \pm \\
2.9\end{array}$ & $\begin{array}{l}3.9 \pm \\
1.5\end{array}$ & 0.462 \\
\hline $\begin{array}{l}\text { Incisional } \\
\text { hernia } \\
\text { localization } \\
\text { M1 } \\
\text { (subxiphoidal) } \\
\text { M2 (epigastric) } \\
\text { M3 (umbilical) } \\
\text { M4 } \\
\text { (infraumbilical) } \\
\text { M5 } \\
\text { (suprapubic) } \\
\text { L1 (subcostal) } \\
\text { L2 (flank) } \\
\text { L3 (iliac) } \\
\text { L4 (lumbar) }\end{array}$ & $\begin{array}{l}- \\
- \\
- \\
- \\
- \\
- \\
- \\
- \\
-\end{array}$ & $\begin{array}{l}- \\
1 \\
- \\
- \\
- \\
- \\
- \\
- \\
-\end{array}$ & 0.619 & $\begin{array}{l}- \\
- \\
- \\
- \\
- \\
- \\
- \\
- \\
-\end{array}$ & $\begin{array}{l}2 \\
1 \\
3 \\
1 \\
1 \\
1 \\
- \\
- \\
-\end{array}$ & 0.274 & $\begin{array}{l}- \\
- \\
- \\
- \\
- \\
- \\
- \\
- \\
-\end{array}$ & $\begin{array}{l}- \\
- \\
3 \\
- \\
- \\
2 \\
- \\
- \\
-\end{array}$ & 0.216 & $\begin{array}{l}1 \\
(1.6) \\
4 \\
(6.3) \\
8 \\
(12.7) \\
5(8) \\
- \\
4 \\
(6.3) \\
2 \\
(3.2) \\
- \\
-\end{array}$ & $\begin{array}{l}2 \\
(2.1) \\
3 \\
(3.1) \\
11 \\
(11.3) \\
4 \\
(4.1) \\
4 \\
(4.1) \\
5 \\
(5.2) \\
7 \\
(7.2) \\
- \\
-\end{array}$ & 0.298 \\
\hline $\begin{array}{l}\text { Incisional } \\
\text { hernia side } \\
\text { Midline } \\
\text { Lateral }\end{array}$ & - & $\begin{array}{l}1 \\
-\end{array}$ & 0.412 & $\begin{array}{l}- \\
-\end{array}$ & $\begin{array}{l}8 \\
1\end{array}$ & 0.423 & - & $\begin{array}{l}3 \\
2\end{array}$ & 0.616 & $\begin{array}{l}19 \\
(30.2) \\
5(8)\end{array}$ & $\begin{array}{l}24 \\
(24.8) \\
12 \\
(12.4)\end{array}$ & 0.293 \\
\hline $\begin{array}{l}\text { Incisional } \\
\text { hernia width } \\
\text { W1 }(<4 \mathrm{~cm}) \\
\text { W2 }(4-10 \mathrm{~cm}) \\
\text { W3 }(\geq 10 \mathrm{~cm})\end{array}$ & $\begin{array}{l}- \\
- \\
-\end{array}$ & $\begin{array}{l}- \\
1 \\
-\end{array}$ & 0.483 & $\begin{array}{l}- \\
- \\
-\end{array}$ & $\begin{array}{l}1 \\
8 \\
-\end{array}$ & $0.027^{a}$ & $\begin{array}{l}- \\
- \\
-\end{array}$ & $\begin{array}{l}- \\
5 \\
-\end{array}$ & $0.053^{b}$ & $\begin{array}{l}12 \\
(19) \\
12 \\
(19) \\
-\end{array}$ & $\begin{array}{l}17 \\
(17.5) \\
19 \\
(19.6)\end{array}$ & 0.833 \\
\hline $\begin{array}{l}\text { Primary } \\
\text { abdominal } \\
\text { hernia (side) } \\
\text { Midline } \\
\text { (Epigastric and } \\
\text { umbilical } \\
\text { hernias) } \\
\text { Lateral } \\
\text { (Spigelian and } \\
\text { lumbar } \\
\text { hernias) }\end{array}$ & $\begin{array}{l}1 \\
-\end{array}$ & - & NA & $\begin{array}{l}1 \\
-\end{array}$ & $\begin{array}{l}2 \\
-\end{array}$ & NA & - & $\begin{array}{l}1 \\
-\end{array}$ & NA & $\begin{array}{l}39 \\
(61.9) \\
-\end{array}$ & $\begin{array}{l}61 \\
(62.9) \\
-\end{array}$ & NA \\
\hline
\end{tabular}




\begin{tabular}{|c|c|c|c|c|c|c|c|c|c|c|c|c|}
\hline \multirow[b]{2}{*}{$\begin{array}{l}\text { Primary } \\
\text { abdominal } \\
\text { hernia (defect } \\
\text { size) } \\
\text { Small }(<2 \mathrm{~cm}) \\
\text { Medium }(2- \\
4 \mathrm{~cm}) \\
\text { Large }(\geq 4 \mathrm{~cm})\end{array}$} & \multicolumn{3}{|c|}{ Recurrence $(n=2)$} & \multicolumn{3}{|c|}{$\begin{array}{l}\text { Foreign Body } \\
\text { Feeling }(n=12)\end{array}$} & \multicolumn{3}{|c|}{ Chronic Pain $(n=6)$} & \multicolumn{3}{|c|}{ All patients $(n=160)$} \\
\hline & $\begin{array}{l}- \\
1 \\
-\end{array}$ & $\begin{array}{l}- \\
- \\
-\end{array}$ & 0.779 & $\begin{array}{l}- \\
1 \\
-\end{array}$ & $\begin{array}{l}- \\
- \\
2\end{array}$ & 0.219 & $\begin{array}{l}- \\
- \\
-\end{array}$ & $\begin{array}{l}- \\
- \\
1\end{array}$ & 0.206 & $\begin{array}{l}- \\
34 \\
(54) \\
5 \\
(7.9)\end{array}$ & $\begin{array}{l}1(1) \\
44 \\
(45.3) \\
16 \\
(16.5)\end{array}$ & 0.146 \\
\hline $\begin{array}{l}\text { Percentages are } \\
\text { NA not applicab } \\
\text { a Foreign body } \mathrm{f} \\
\text { b Chronic pain a }\end{array}$ & ing & & $\begin{array}{l}\text { ateral, } \\
\text { ional } \\
\text { rnia re }\end{array}$ & erni & & $\begin{array}{l}\text { anium } \\
\text { as not o } \\
\text { bserved }\end{array}$ & & & $\begin{array}{l}\text { ropylene } \\
\text { tanium } \\
\text { group }\end{array}$ & $\begin{array}{l}\text { roup } \\
\text { oup }\end{array}$ & & \\
\hline
\end{tabular}

\section{Discussion}

In the present study showed that in onlay VHR, the use of TCM did not affect recurrence but significantly reduced foreign body feeling and chronic pain by a significant degree compared to PM. SSI appears to be linked to increased recurrence of two meshes in this repair. Moreover, the increase in defect size was associated with both foreign body feeling and chronic pain in onlay VHR with PM.

Currently, the use of mesh for incisional hernia repair is recommended at Grade A level from Oxford Centre of Evidence-Based Medicine [9]. Nevertheless, which technique is best for VHR is still controversial. Wéber et al. identified less recurrence with the onlay technique compared to the sublay technique for large ventral hernias (>25 $\mathrm{cm}^{2}$ ) [10]. In contrast, in the meta-analysis by Timmermanns et al., the sublay technique was stated to cause less SSI and recurrence compared to the onlay technique for incisional hernia repair [11]. Similarly, in the review by Liang et al. in 2017, the sublay technique was recommended for incisional hernia repair [12]. Additionally, if the onlay technique is to be used, it was emphasized that care needs to be taken of many factors like patient selection, surgeon experience, careful dissection and prophylactic measures (drainage, abdominal binders, etc.) to reduce possible complications. In the present study, all operations were performed with the onlay technique and our reason for choosing this technique is that our surgical experience was greater with onlay repair.

In a nationwide prospective study of the Danish Ventral Hernia Database, Helgstrand et al. found that a large hernia defect $(>7 \mathrm{~cm})$ was stated to be statistically associated with recurrence for onlay incisional hernia repair [13]. In contrast, in the present study, only in patients using PM was the increase in defect size significantly associated with foreign body feeling and chronic pain; however, there was no significant increase observed in recurrence rates. On the other hand, the authors have many advantages like greater patient numbers, comparison of different surgical techniques, and assessment of early and late complications in their study compared to this study. However, the authors stated they did not analyse factors like smoking habits, BMI and comorbidities in their study. These parameters were investigated in this study, but no significant correlation was identified between these factors with recurrence, foreign body feeling and chronic pain. In onlay VHR, if we consider that the use of a mesh with larger surface area is required with the increase in defect size. Thus, we can state that the greater surface area of the mesh may be the factor affecting formation of mesh-related complications [13]. For example, in a retrospective cohort study by Kroese et al. in 2018, investigated external validation of the EHS classification for a postoperative complication after incisional hernia repair [14]. They found that there were significant differences between W1 and 
W3 class hernia in terms of postoperative complications (wound, medical and surgical) $(p<0.001)$. Likewise, investigated this classification in this study too. However, no patient with W3 class hernia was observed. Nevertheless, the EHS width classification was associated with foreign body feeling and chronic pain in the polypropylene group $(p<0.001)$. Additionally, the authors stated the EHS width classification is associated with postoperative complications. Likewise, the results of this study suggest that the EHS width classification is useful for predicting the foreign body feeling and chronic pain after incisional hernia repair. In another prospective study of the authors, primary and incisional hernia were compared in terms of postoperative complications [15]. They found overall complication rates (wound, surgical, and medical) were significantly different (4.4\%) for primary hernia versus $(15 \%)$ incisional hernia $(p<0.001)$. Similarly, in this study, found a same result for foreign body feeling and chronic pain $(p=0.029)$.

Recurrence is one of the complications that can develop after VHR and is an undesirable situation for both patient and surgeons. Though there are many factors increasing recurrence, one of the most commonly blamed factors is DM [16]. Moreover, for DM, a HbA1c >7\% has been found to be associated with an increased risk of wound infection [17]. As a result, diabetic patients with poor blood sugar control have increased SSI which increases the possibility of recurrence. In this study, two patients with recurrence identified had DM and one of these patients had HbA1c level above 7\%. However, two patients had SSI. In this study, though not statistically, we think the recurrence rate was clinically significantly increased by DM. Today, the incisional hernia repair still has a high incidence of SSI $(0.7 \%-26.6 \%)$ [18]. In a prospective study by Juvany et al. in 2018 , stated that SSI significantly increased one-year recurrence rate $(16 \%)$ for elective incisional hernia repair $(p=0.047)$ [19]. However, they found that the only risk factor identified for SSI by the multivariable analysis was the presence of seroma and hematoma $(p=0.042)$. The results of this study were very similar in terms of seroma and SSI. A review by Köckerling in 2018, stated that the mean recurrence rate was $9.9 \%(0-32)$ at follow-up of 1-8 years for onlay VHR [20]. In this study, the recurrence rate was $1.25 \%$, with a mean follow-up duration of 28 months for all patients. Though many factors may play a role in this difference in recurrence rates, we think it may be due to the shorter follow-up duration in this study. In the literature, there are studies researching the correlation between mesh weight and recurrence in hernia repair. For example, a randomized prospective study by O'Dwyer et al. stated that the use of lightweight mesh for inguinal hernia repair caused less recurrence than the use of heavyweight mesh [21]. Conversely, in studies comparing TCM with PM as in this study, Schopf et al. [22] and Koch et al. [23] stated the opposite and suggested that there was no significant difference between both meshes regarding recurrence. Likewise, in this study, no difference was found between meshes in terms of recurrence.

It is well known that meshes used for hernia repair cause inflammation and this leads to foreign body reactions. Post et al. stated that a foreign body reaction caused by meshes leads to foreign body feeling [24]. In another study by Orenstein et al., it was stated that lightweight meshes lead to less foreign body feeling than heavyweight meshes [25]. Similarly, in several experimental studies, it was stated that TCM led to less foreign body reaction than identical meshes $[26,27]$. In this study, foreign body feeling was found to be significantly less in patients with TCM. We think that the reason for this is that the mesh used was a lightweight mesh.

Chronic pain is also a common complication of VHR and multifactorial in aetiology [28]. The most important factors in the aetiology are surgeon experience, surgical technique and mesh characteristic. This pain is mostly associated with the mesh itself and frequently is related to a foreign body reaction and inflammation tissue response caused by the mesh and stiffness and shrinkage ensuing as a result [29]. In the literature, there are studies researching the correlation between inflammatory response and mesh weight. For instance, in an experimental study by Junge et al. in 2005, no incompatibility was observed in terms of biocompatibility between lightweight

Page $10 / 16$ 
TCM and heavyweight PM, and they showed that inflammatory response was considerably low [30]. Similarly, Pereira-Lucera et al. reported that an inflammatory response was significantly low for lightweight TCM compared to meshes containing polyglactin + polypropylene [31]. Generally, in these studies, lightweight TCM was shown to cause less foreign body reaction and scarring compared to heavyweight PM. These results support the lower chronic pain rates among patients using TCM in the present study. On the other hand, in the literature, there are studies analysing the chronic pain rates in VHR performed with different techniques. Similar to the present study, in a study about onlay repair with PM, Kingsnorth found the incidence of chronic pain to be $18 \%$ in patients with large abdominal defect $(>10 \mathrm{~cm}$ ) [32]. However, different from this study, the authors added component separation and fibrin sealant to this technique. With the underlay technique, another study with lightweight mesh by Gronnier et al. with 109 patients and mean 24-month follow-up stated 34\% had chronic pain [8]. The authors identified that chronic cough (a cough lasting eight weeks or longer) significantly increased the chronic pain rate. In the current study, no patient with large abdominal defect was observed and chronic cough was not assessed. Chronic pain identified at lower rate in both mesh groups in this study. We think that a lack of the large abdominal defect in this study could affect chronic pain rates. A prospective study by Welty et al. assessed patients with sublay technique using different weight meshes in terms of chronic pain [33]. They found the chronic pain rates (at rest and during heavy work) according to mesh weights (heavy, mid and lightweight) were $17 \%, 6 \%, 7 \%$ vs. $9 \%, 3 \%$ and $0 \%$, respectively. In this study, these rates were $1 \%, 6.2 \%$ vs. $0 \%$ and $0 \%$, respectively. A common point between the studies by Wind et al. and this study is that though different surgical techniques were applied, the reduction in weight of the mesh significantly reduced chronic pain rates. Generally, the chronic pain rates in this study are partly consistent with the literature.

There are several limitations to the findings of the current study. Firstly, this study was retrospective and conducted with a limited number of patients. Secondly, owing to the VAS scale not having a specific identification and pain being a subjective finding, type 1 errors may be present at the statistical significance level. Due to the retrospective design of this study, we could not perform strong and valid tools like the Carolinas Comfort Scale or McGill Pain Scale for postoperative pain and functionality. Despite these limitations, the advantage of our study is that operations were performed by a single surgeon and it is a single-centre study. Moreover, one of the other advantages is that there are very few studies in the literature about recurrence, foreign body feeling and chronic pain in the long run when lightweight TCM is used for VHR. Although this study focuses on the effects of TCM on recurrence, foreign body feeling and chronic pain, many findings were also detected about SSI and seroma in onlay VHR with TCM. Therefore, further studies, which take these variables into account, will need to be undertaken.

\section{Conclusions}

As a result, in onlay VHR, TCM leads to less foreign body feeling and chronic pain than PM and no significant differences were found in terms of recurrence between the two meshes. SSI is a risk factor for recurrence both meshes in this surgery. Additionally, the increase in defect size was associated with foreign body feeling and chronic pain after using PM. We think there is a need for studies with larger populations using prospective and objective parameters to further enlighten this topic.

\section{Abbreviations}

\section{TCM}

Titanium-coated meshes

PM

Page $11 / 16$ 
Polypropylene mesh

VH

Ventral hernia

VHR

Ventral hernia repair

ASA

American Society of Anesthesiologists

VAS

Visual analogue scale

EHS

European Hernia Society

SSI

Surgical site infection

HbA1c

Haemoglobin A1C

W

Width

\section{Declarations}

\section{Ethics declarations}

\section{Ethics approval and consent to participate}

All procedures performed in studies involving human participants were in accordance with ethical standards of the institutional and/or national research committee and with the 1964 Helsinki declaration and later amendments or comparable ethical standards. This retrospective study was performed with approval from the Ethics Committee of Ordu University. A written informed consent from the patients was waived because this study was performed retrospectively.

\section{Consent for publication}

Not applicable.

\section{Competing interests}

The author(s) declare that they have no competing interests.

Meeting presentation This study was presented as poster presentation at the 41st Annual Congress of the European Hernia Society: Evidence, Innovation, Education. September 11-14, 2019- Hamburg, Germany.

\section{Funding}

The author(s) received no financial support for the research, authorship, and/or publication of this article.

\section{Author's contributions}


Protocol/project development: C.A. Data acquisition and interpretation of data: C.A. Statistics analysis of data: C.A. Manuscript drafting: C.A. Manuscript Revision and accountable for all aspects of the study: C.A. All authors read and approved the final manuscript.

\section{Acknowledgements}

No acknowledgements to be declared.

Availability of data and materials: All data were obtained retrospectively from chart review.

\section{References}

1. Muysoms FE, Miserez M, Berrevoet F, Campanelli G, Champault GG, Chelala E, et al. Classification of primary and incisional abdominal wall hernias. Hernia. 2009;13.

2. -14. https://doi.org/10.1007/s10029-009-0518-x.

3. Walgenbach $M$, Mathes $T$, Siegel R, Eikermann M. Mesh fixation techniques in primary ventral or incisional hernia repair. Cochrane Database of Systematic Reviews,2015;3. https.

4. //doi.org/10.1002/14651858.CD011563.

5. Cassar K, Munro A. Surgical treatment of incisional hernia. Br J Surg. 2002;89.

6. -545. https://doi.org/10.1046/j.1365-2168.2002.02083.x.

7. Burger JW, Luijendijk RW, Hop WCJ, Halm JA, Verdaasdonk EG, Jeekel J. Long-term follow-up of a randomized controlled trial of suture versus mesh repair of incisional hernia. Ann Surg. 2004;240.

8. -585. https://doi.org/10.1097/01.sla.0000141193.08524.e7.

9. Cevasco M, Itani KM. Ventral hernia repair with synthetic, composite, and biologic mesh.

10. Characteristics. indications, and infection profile. Surg Infect (Larchmt). 2012;13:209-15. https://doi.org/10.1089/sur.2012.123.

11. Klinge $U$, Klosterhalfen B. Modified classification of surgical meshes for hernia repair based on the analyses of 1,000 explanted meshes. Hernia. 2012;16.

12. -258. https://doi.org/10.1007/s10029-012-0913-6.

13. Köckerling F, Schug-Pass C. What do we know about titanized polypropylene meshes? An evidence-based review of the literature. Hernia. 2014;18.

14. -457. https://doi.org/10.1007/s10029-013-1187-3.

15. Gronnier C, Wattier JM, Favre H, Piessen G, Mariette C. Risk factors for chronic pain after open ventral hernia repair by underlay mesh placement. World J Surg. 2012;36(7).

16. -1554. https://doi.org/10.1007/s00268-012-1523-2.

17. Köckerling F. Recurrent Incisional Hernia Repair-An Overview. Front Surg. 2019;6.

18. https://doi.org/10.3389/fsurg.2019.00026.

19. Wéber G, Baracs J, Horváth ÖP. “Onlay” mesh provides significantly better results than "sublay” reconstruction. Magy Seb. 2010;63.

20. -11. https://doi.org/10.1556/MaSeb.63.2010.5.3.

21. Timmermanns L, De Goede B, van Dijk SM, Kleinrensink GJ, Jeekel J, Lange JF. Meta-analysis of sublay versus onlay mesh repair in incisional hernia surgery. Am J Surg. 2014;207.

Page $13 / 16$ 
22. -8. https://doi.org/10.1016/j.amjsurg.2013.08.030.

23. Liang MK, Holihan JL, Itani K, Alawadi ZM, Flores Gonzalez JR, Askenasy EP. Ventral hernia managementexpert consensus guided by systematic review. Ann Surg. 2017;265.

24. -9. https://doi.org/10.1097/SLA.0000000000001701.

25. Helgstrand F, Rosenberg J, Kehlet H, Jorgensen LN, Bisgaard T. Nationwide prospective study of outcomes after elective incisional hernia repair. J Am Coll Surg. 2013;216.

26. -28. https://doi.org/10.1016/j.jamcollsurg.2012.10.013.

27. Kroese LF, Kleinrensink GJ, Lange JF, Gillion JF, Hernia C. External validation of the European Hernia Society Classification for postoperative complications after incisional hernia repair.

28. a cohort study. of 2191 patients. J Am Coll Surg. 2018;226(3):223-9.e1. https://doi.org/10.1016/j.jamcollsurg.2017.11.018.

29. Kroese LF, Gillion JF, Jeekel J, Kleinrensink GJ, Lange JF, Hernia-Club M. Primary and incisional ventral hernias are different in terms of patient characteristics and postoperative complications-a prospective cohort study of 4565 patients. Int J Surg. 2018;51.

30. -119. https://doi.org/10.1016/j.ijsu.2018.01.010.

31. Dietz UA, Winkler MS, Hartel RW, Fleischhacker A, Wiegering A, Isbert C, et al. Importance of recurrence rating, morphology, hernial gap size, and risk factors in ventral and incisional hernia classification. Hernia. 2014;18.

32. -30. https://doi.org/10.1007/s10029-012-0999-x.

33. Dronge AS, Perkal MF, Kancir S, Concato J, Aslan A, Rosenthal RA. Long term glycemic control and postoperative infectious complications. Arch Surg. 2006;141.

34. -80. https://doi.org/10.1001/archsurg.141.4.375.

35. Management of mesh infection

Beffa LR, Warren JA. Management of mesh infection. In.

36. Hope WW, Cobb WS, Adrales GL, editors Textbook of Hernia. Cham, Switzerland:Springer International Publishing, 2017;395-405.

37. Impact of surgical site infections on elective incisional hernia surgery

Juvany M, Hoyuela C, Trias M, Carvajal F, Ardid J, Martrat A. Impact of surgical site infections on elective incisional hernia surgery.

38. A prospective study

19:339 - 44

https://doi.org/10.1089/sur.2017.233

A prospective study. Surg Infect (Larchmt). 2018;19:339 - 44. https://doi.org/10.1089/sur.2017.233.

39. Köckerling F. Onlay technique in incisional hernia repair - A systematic review. Front Surg. 2018;5.

40. https://doi.org/10.3389/fsurg.2018.00071.

41. O’Dwyer PJ, Kingsnorth AN, Molloy RG, Small PK, Lammers B, Horeyseck G. Randomized clinical trial assessing impact of a lightweight or heavy-weight mesh on chronic pain after inguinal hernia repair. Br J Surg. 2005;92.

42. - 170. https://doi.org/10.1002/bjs.4833.

43. Chronic pain after laparoscopic transabdominal preperitoneal hernia repair Schopf S, von Ahnen T, von Ahnen M, Schardey H. Chronic pain after laparoscopic transabdominal preperitoneal hernia repair. 
44. a randomized comparison of light and extralight titanized polypropylene mesh. World J Surg. 2011;35:302-10. https://doi.org/10.1007/s00268-010-0850-4.

45. Koch A, Bringman S, Myrelid P, Smeds S, Kald A. Randomized clinical trial of groin hernia repair with titaniumcoated lightweight mesh compared with standard polypropylene mesh. Br J Surg. 2008;95(10).

46. -1231. https://doi.org/10.1002/bjs.6325.

47. Post S, Weiss B, Willer M, Neufang T, Lorenz D. Randomized clinical trial of lightweight composite mesh for Lichtenstein inguinal hernia repair. Br J Surg. 2004;91.

48. -48. https://doi.org/10.1002/bjs.4387.

49. Orenstein SB, Saberski ER, Kreutzer DL, Novitsky YW. Comparative analysis of histopathologic effects of synthetic meshes based on material, weight, and pore size in mice. J Surg Res. 2012;176.

50. -9. https://doi.org/10.1016/j.jss.2011.09.031.

51. Influence of titanium coating on the biocompatibility of a heavyweight polypropylene mesh Scheidbach H, Tannapfel A, Schmidt U, Lippert H, Köckerling F. Influence of titanium coating on the biocompatibility of a heavyweight polypropylene mesh.

52. an animal experimental model. Eur Surg Res. 2004;36:313-7. https://doi.org/10.1159/000079917.

53. SchugPass C, Tamme C, Tannapfel A, Köckerling F. A lightweight polypropylene mesh (TiMesh) for laparoscopic intraperitoneal repair of abdominal wall hernias.

54. comparison of biocompatibility. with the DualMesh in an experimental study using the porcine model. Surg Endosc. 2006;20:402-9. https://doi.org/10.1007/s00464-004-8277-3.

55. Berger D. Diagnostics and therapy of chronic pain following hernia operation. Chirurg. 2014;85.

56. -20. https://doi.org/10.1007/s00104-013-2594-9.

57. Sajid MS, Kalra L, Parampalli U, Sains PS, Baig MK. A systematic review and meta-analysis evaluating the effectiveness of lightweight mesh against heavyweight mesh in influencing the incidence of chronic groin pain following laparoscopic inguinal hernia repair. Am J Surg. 2013;205(6).

58. -36. https://doi.org/10.1016/j.amjsurg.2012.07.046.

59. Titanium coating of a polypropylene mesh for hernia repair Junge K, Rosch R, Klinge U, Saklak M, Klosterhalfen B, Peiper C, et al. Titanium coating of a polypropylene mesh for hernia repair.

60. effect on biocompatibility. Hernia. 2005;9:115-9. https://doi.org/10.1007/s10029-004-0292-8.

61. Experimental study comparing meshes made of polypropylene polypropylene + polyglactin and polypropylene + titanium Pereira-Lucena CG, Artigiani-Neto A, Lopes-Filho GJ, Frazao CV, Goldenberg A, Matos D, et al. Experimental study comparing meshes made of polypropylene, polypropylene + polyglactin and polypropylene + titanium.

62. Inflammatory cytokines. histological changes and morphometric analysis of collagen. Hernia. 2010;14:299304. https://doi.org/10.1007/s10029-009-0621-z.

63. Kingsnorth A. Open onlay mesh repair for major abdominal wall hernias with selective use of components separation and fibrin sealant. World J Surg. 2008;32.

64. -30. https://doi.org/10.1007/s00268-007-9287-9.

65. Welty G, Klinge U, Klosterhalfen B, Kasperk R, Schumpelick V. Functional impairment and complaints following incisional hernia repair with different polypropylene meshes. Hernia. 2001;5. 


\section{Figures}

\section{Assessed for eligibility}

$$
(n=192)
$$

Excluded $(n=30)$ :

- Under 18 years of age $(n=9)$

- Strangulated hernia $(n=4)$

- A past medical history of ostomy or malignancy $(n=2)$

- ASA scores $\geq 4(n=5)$

- A history of chemotherapy or radiotherapy $(n=4)$

- Could not be accessed $(n=6)$

\section{Mesh Types \\ $(n=162)$}

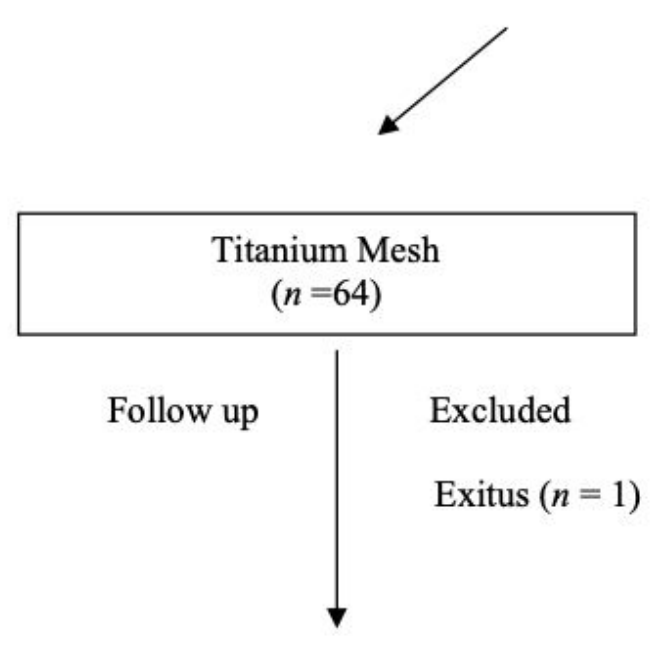

Analyzed $(n=63)$
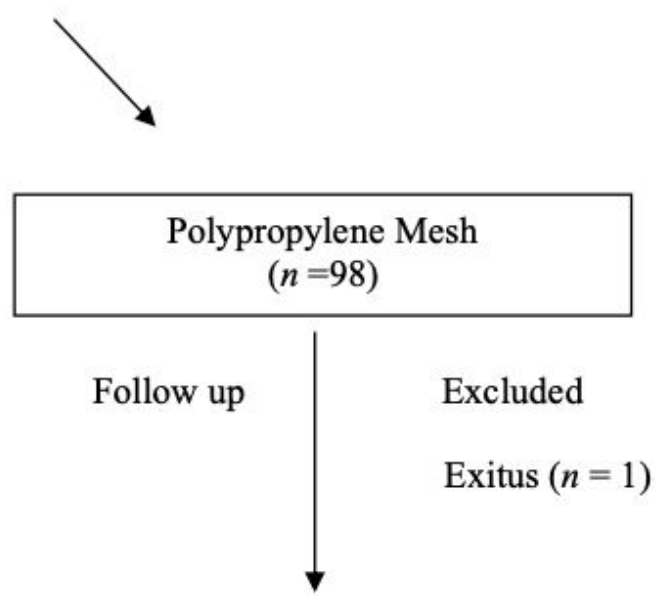

Analyzed $(n=97)$

Figure 1

Figure 1 